\title{
Literature Review : Efektivitas Terapi Non Farmakologi Terhadap Penurunan Tekanan Darah Pada Pasien End Stage Renal Disease Yang Menjalani Hemodialisis
}

\author{
Nurul Pradita ${ }^{1}$, Kiki Hardiansyah Safitri ${ }^{2}$ \\ ${ }^{1}$ Mahasiswa Program Studi NERS, ITKES Wiyata Husada, Jl.Kadrie Oening No 77 Samarinda, Kalimantan Timur \\ e-mail : nurulpradita478@gmail.com \\ ${ }^{2}$ Dosen, ITKES Wiyata Husada, Jl.Kadrie Oening No 77 Samarinda, Kalimantan Timur \\ e-mail : kikihardiansyahs@stikeswhs.ac.id
}

\begin{abstract}
ABSTRAK
Latar Belakang: End Stage renal disease (ESRD) bisa disebabkan oleh tekanan darah yang tidak terkontrol (hipertensi) atau penyakit ginjal dapat menyebabkan hipertensi. Terapi non farmakologi dapat membantu pasien mengatasi tekanan darah dengan efek samping yang minimal. Tujuan: Mengidentifikasi studi literatur efektifitas terapi non farmakologi terhadap penurunan tekanan darah pada pasien end stage renal disease. Metode: Desain penelitian Literature Review, online database adalah jurnal Science Direct, PubMed(NCBI), google scholar. Jurnal yang digunakan dalam kurun kurun waktu 2012-2020, pencarian menggunakan Populasi : pasien ESRD dengan hipertensi, intervensi :terapi non farmakologi, comparison: terapi komplomentar, outcome:penurunan tekanan darah, study design : literature review dan quasi experiment. Hasil: Didapatkan 6893 jurnal, diseleksi menggunakan kriteria inklusi dan ekslusi,melalui diagram prisma didapatkan menjadi 12 jurnal. Terapi non farmakologi yang digunakan adalah progressive muscel relaxation (4 jurnal); terapi massase (1 jurnal); terapi music (4 jurnal); intradialitic exercise (4 jurnal) Kesimpulan: Terapi non farmakologi bermakna di dalam studi literature untuk menurunkan tekanan darah yang bekerja dengan prinsip relaksasi, berpengaruh dalam peningkatan hormon endorphin yang menyebabkan pembuluh darah berdilatasi sehingga tekanan darah mengalami penurunan.
\end{abstract}

Kata Kunci : Terapi Non farmakologi, Hipertensi, End Stage Renal Disease

\begin{abstract}
Background: End Stage Renal Disease (ESRD) can be caused by uncontrolled blood pressure (hypertension) or kidney disease can cause hypertension. Non-pharmacological therapy can help patients with blood pressure with minimal side effects. Objective: To conduct a literature study on the effectiveness of non-pharmacological therapies in reducing blood pressure of End Stage Renal Disease patients. Method: Literature Review research design, the data were obtained from online database such as Science Direct, PubMed (NCBI), and google scholar in the period of 2012-2020. The Population in this study was ESRD patients with hypertension and the intervention given were nonpharmacological therapies, comparison: commentary therapy, outcome: lowering blood pressure, study design: literature review and quasi experiment. Results: There were 6893 journals, selected using inclusion and exclusion criteria, through the PRISMA diagram they were narrowed down into 12 journals. The non-pharmacological therapies used were progressive muscle relaxation (4 journals); massage therapy (1 journal); music therapy (4 journals); and intradialytic exercise (4 journals). Conclusion: Non-pharmacological therapy is significant in literature studies to reduce blood pressure which works with the principle of relaxation. Further, it has an effect in increasing the endorphin hormone which causes blood vessels to dilate and lead to decreasing blood pressure.
\end{abstract}

Keywords: Non pharmacological, Hypertension, End Stage Renal Disease 


\section{PENDAHULUAN}

End Stage Renal Disease merupakan suatu proses kerusakan sel-sel ginjal dengan rentang waktu lebih dari 3 bulan. Proses perjalanan penyakit dari end stage renal disease disebabkan oleh berbagai etiologi yang beragam secara progresif menurunkan fungsi dari ginjal, sehingga lama-kelamaan ginjal akan mengalami kehilangan fungsinya yang disebut dengan gagal ginjal. Ketidakmampuan ginjal dalam menjalankan fungsi menyebabkan terjadi akumulasi produk sisa metabolisme (retensi urea dan sampah nitrogen lain dalam darah) dan keseimbangan cairan dan eletrolit yang akan mempengaruhi seluruh sistem tubuh. Kerusakan sel ginjal bersifat irreversible, pada end stage renal disease diperlukan terapi hemodialisis. end stage renal disease merupakan penyakit terminal, dimana kerusakan secara terus menerus dan tidak dapat disembuhkan, pada tahap ini fungsi ginjal tidak dapat kembali normal, sehinga diperlukan dialisis seumur hidup.(Agustina \& E Purnomo, 2019)

Pasien dengan end stage renal disease di indonesia yang menjalani hemodialisis cukup tinggi di Indonesia, yaitu berdasarkan data Indonesia Renal Registry (IRR) dari Perhimpunan Nefrologi Indonesia (pernefri) diketahui bahwa total insiden pasien baru dan aktif di tahun 2018 adalah 66433 orang. Data Riset Kesehatan Dasar (Riskesda) tahun 2013 didapatkan bahwa prevalensi dan insiden gagal ginjal kronik di Indonesia adalah sekitar $0,2 \%$ atau 2 per 1000 penduduk dan prevalensi batu ginjal sebesar $0,6 \%$ atau 6 per 1000 penduduk. Hanya 60\% dari klien gagal ginjal kronis tersebut yang menjalani terapi dialisis). Prevalensi di Provinsi Kalimantan Timur penyakit gagal ginjal kronis $0,1 \%$ dari penduduk dari klien gagal ginjal kronis di Indonesia, yang mencakup klien mengalami pengobatan, terapi penggantian ginjal, dialysis peritoneal dan Hemodialisis pada tahun Hemodialisis terbukti efektif mengeluarkan cairan, elektrolit dan sisa metobolisme tubuh, sehingga secara tidak langsung bertujuan untuk memperpanjang umur pasien. Prosedur hemodialisis bukan berarti tidak memiliki resiko. Meskipun, Hemodialisis bermanfaat bagi pasien, namun bukan berarti tanpa efek samping. Berbagai permasalah dan komplikasi dapat terjadi saat pasien menjalani hemodialisis (shahgoblian, ghafourifard, rafieian \& mortazavi, 2008). Salah satu komplikasi yang dapat terjadi pada saat menjalani terapi hemodialisis atau biasa disebut komplikasi adalah hipertensi (daugridas, blake \&Ing, 2007).

Terapi non farmakologi adalah suatu terapi yang dilakuakan untuk menurunkna gejala tanpa menggunakan obat dan suatu terapi yang menimbulkan efek samping yang kecil bahkan tidak menimbulkan efek samping. Terapi non farmakologi yang bisa dilakukan oleh perawat dengan pengaturan 
diet, latihan fisik, pendidikan kesehatan (penyuluhan ), edukasi psikologis yang didalamnya terdapat teknik biofeedback, teknik relaksasi dan terapi komplementer untuk menurunkan tekanan darah sehingga tidak mengalami progresifitas dan menyebabkan komplikasi serta kematian.

Dengan adanya terapi non farmakologi yang dapat menurunkan tekanan darah tanpa menimbulkan efek samping,oleh karena itu perlu dilakukan rangkuman literature yang bertujuan untuk menganalisis efektifitas terapi non farmakologi terhadap penurunan tekanan darah pada pasien end stage renal disease.

\section{METODE PENELITIAN}

Desain penelitian digunakan untuk menjawab pertanyaan penelitian, metode pada penelitian ini adalah studi literatur. Studi literature digunakan untuk mengidentifikasi, menganalisis, dan mensintesis jurnal-junal melalui proses yang sistematis. Literatur yang digunakan berjumlah 10-20 jurnal melalui proses pencarian yang telah ditetapkan atau direncanakan oleh peneliti.

Database Jurnal adalah sumber data yang digunakan dalam proses pencarian jurnal yang meliputi, Science Direct, PubMed(NCBI), , google scholar, pencarian literature dilakukan dalam kurun waktu tahun 20122020. Data yang didapatkan merupakan data dari hasil penelitian-penelitian sebelumnya yang berupa artikel dan jurnal. 
Tabel 1 Kata Kunci Studi Literatur

\section{Tabel 2 Format PICOS dalam Literature}

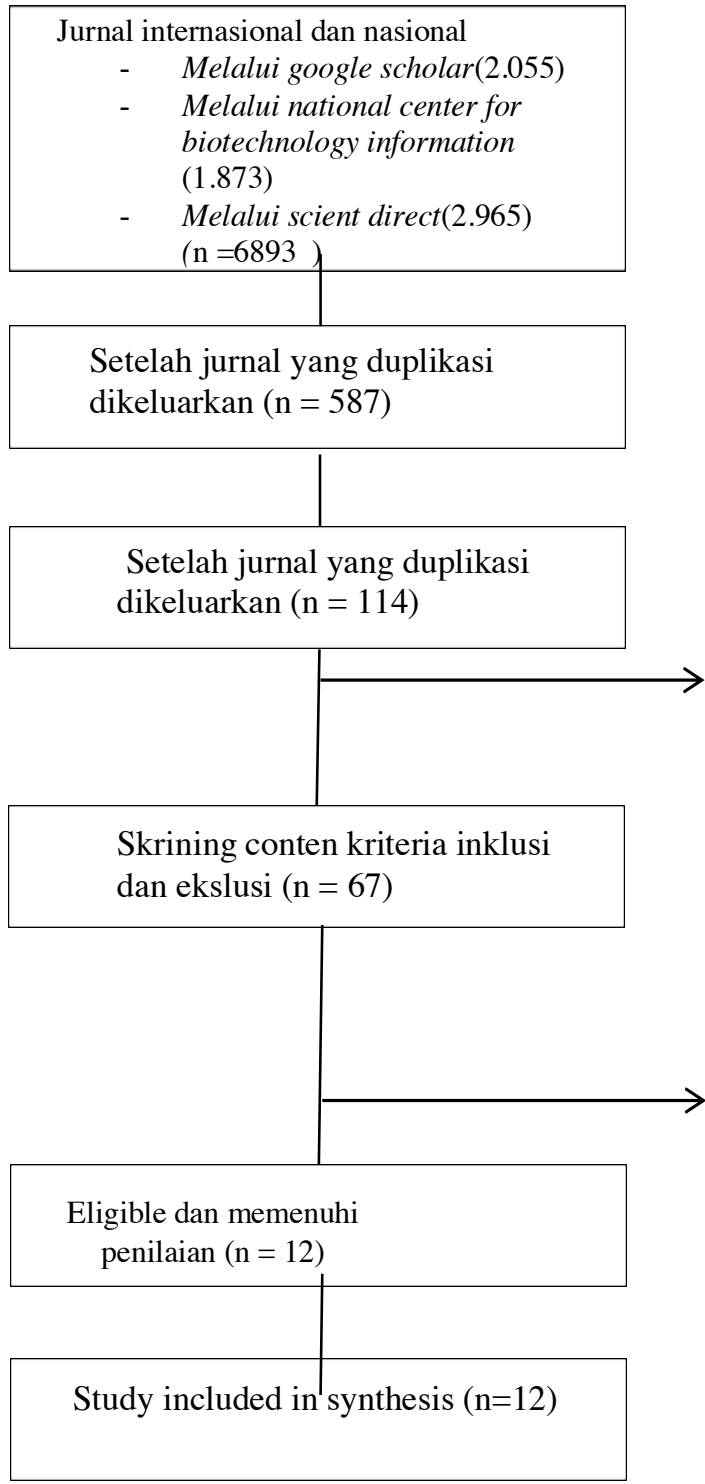

\section{HASIL PENELITIAN}

Berdasarkan hasil pencarian literature melalui publikasi di tiga database dan menggunakan kata kunci yang sudah disesuaikan dengan $\mathrm{MeSH}$, peneliti

\begin{tabular}{lll}
\hline $\begin{array}{l}\text { End stage renal } \\
\text { disease }\end{array}$ & $\begin{array}{l}\text { Blood } \\
\text { pressure }\end{array}$ & $\begin{array}{l}\text { Nursing } \\
\text { intervention }\end{array}$ \\
\hline OR & OR & OR \\
\hline $\begin{array}{l}\text { Cronic kidney } \\
\text { disease }\end{array}$ & $\begin{array}{l}\text { Lower blood } \\
\text { pressure }\end{array}$ & Terapi \\
\hline OR & OR & OR \\
\hline $\begin{array}{l}\text { Gagal ginjal } \\
\text { kronis }\end{array}$ & $\begin{array}{l}\text { Hypertension } \\
\text { / hipertensi }\end{array}$ & $\begin{array}{l}\text { Terapi farmakologi } \\
\text { fan }\end{array}$ \\
\hline
\end{tabular}

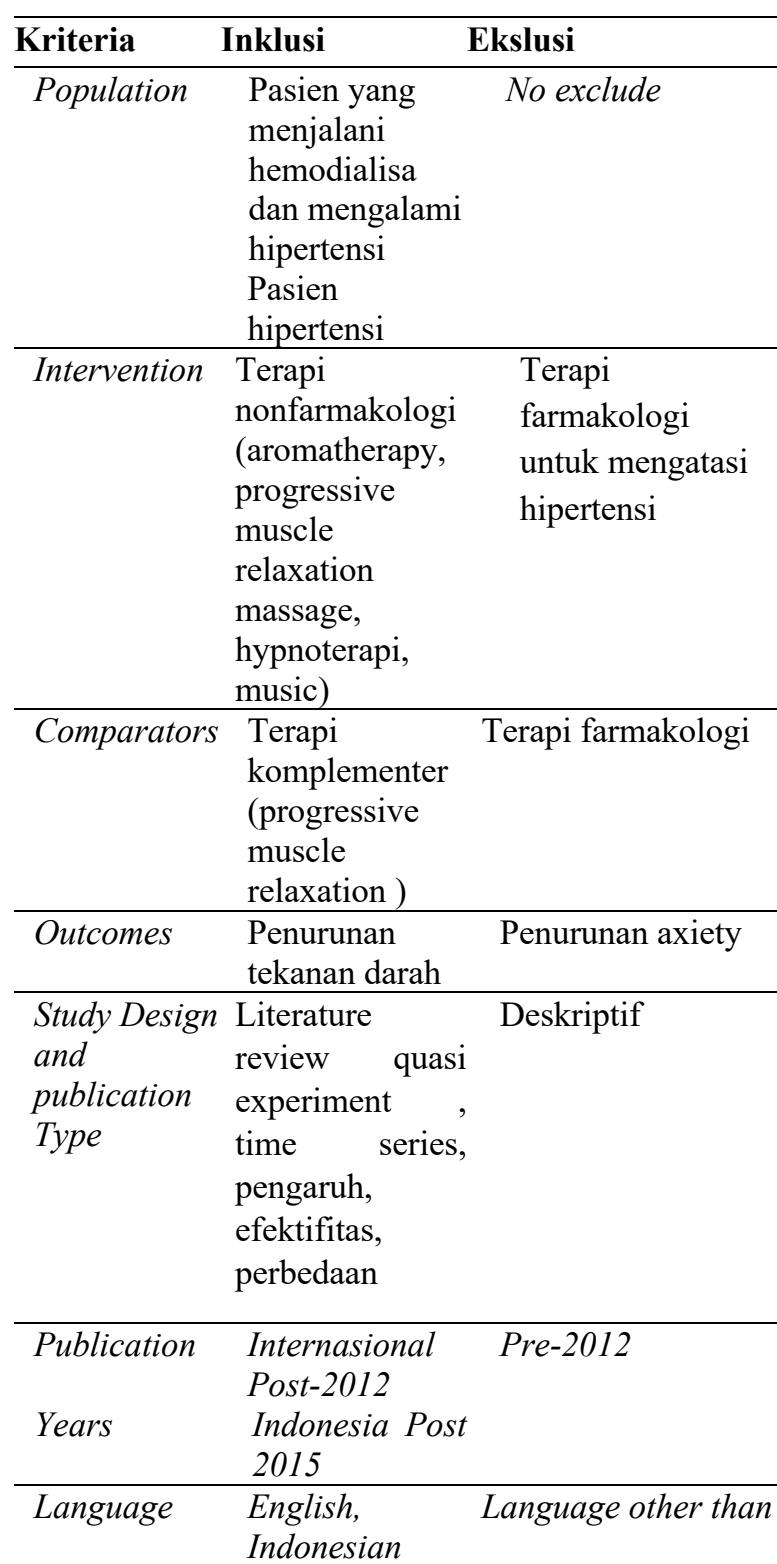

English and Indonesian

mendapatkan menemukan 6893 temuan, kemudian dipersempit dengan mengklasifikasikan dengan kata kunci ESRD 
and hypertension and nursing intervention lalu ditemukan 587, setelah itu dipilih sesuai kriteria inklusi dan ekslusi didapatkan hasil 67 dan disharing dengan penilaian prisma menjadi 12 sampel.

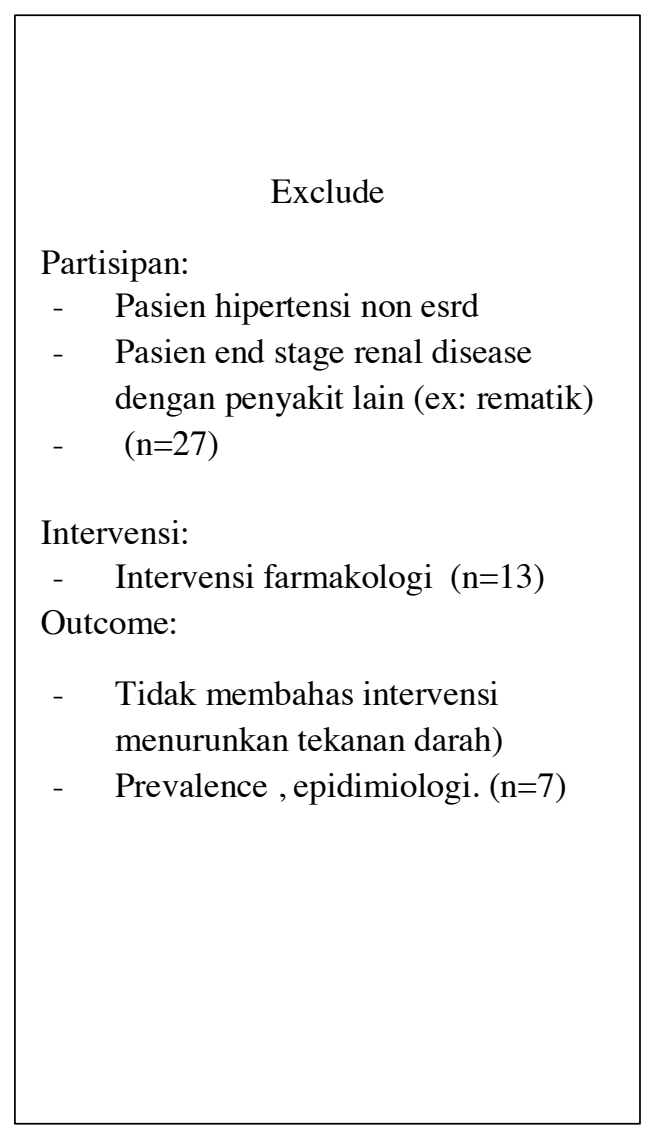
$+2$
Exclude
Partisipan:
- Tidak focus pada penurunan tekanan darah $(n=33)$
Intervensi:
- Tiak relevan dengan terapi non farmakologi $(n=12)$

Outcome:

- Tidak membahas penurunan tekanan darah $(\mathrm{n}=10)$
} 
Jurnal Keperawatan Wiyata

Volume 1, Nomor 1, Tahun 2020

ISSN 2774-4558 (Cetak)

\section{ISSN 2774-9789 (Online)}

No $1 . \quad$ Peneliti : Niken Setyaningrum

Tahun : 201

Efektivitas Progressive Muscle Relaxation Dan Slow Deeb Breathing Terhadap Penurunan Tekanan Darah Pad

Penderita Hipertensi Di Wilayah Kerja Puskesmas

Gamping 2 Yogyakarta

masyarakat voleme 11 no keperawatan dan ilmu kesehatan

Jenis metodologi penelitian:

Quasi experimental with comparison group dengan teknik

Tempat : Indones

Sampel :
Pasien hip

tensi yang berada

wilayah kerja puskesmas gamping 2

Yogyakarta Kriteria inklusi :

Semua penderita hipertensi primer ta

Kriteria elslusi :-

Jumlah : 60 responden, dengan 20

orang setiap masing intervensi, gru

control 1 dan grop control 2 .

Purposive sampling.

(1)

Jenis intervers:

Terapi komplen: : (por

dilaston : Dari hasil penelitian didapatkan hasil bahwa

Kelompok intervensi dengan progressive muscle

Teknik progressive muscle relaxation dan slow deep breating dilakukan Terapi slow deep untuk menurunkan tekanan darah dibandingkan

selama 15 hari . pada hari ke 15 dilakukan post test pengukuran tekanan

Frekensi:

Instrument : Sphygmomanometer dan lembar observasi untuk mencatat

breating untuk

kelompok control 1 dan 2 .

$\begin{array}{ll}\begin{array}{l}\text { menurunkan tekanan } \\ \text { darah. }\end{array} & \begin{array}{l}\text { Pada tekanan darah systole didapatkan hasil } \\ (\mathrm{p}=0.001)\end{array} \\ \text { tekanan darah diastole didapatkan hasi }\end{array}$

Penan darah.

Posedur pelaksanaan :
Peneliti mendapat data dari puskesmas gamping 2 terkait nama dan alamat

penderita hipertensi yang rutin control di puskesmas gamping 2 .pengukura

itu responden diajarknan teknik progressive muscle relaxation dan slow deep breating

Sampel:
Pasien hipertensi yang berada di

Pahun : 2018

Perbedaan efektifitas progressive muscle relaxation (PMR) dengan slow deep breathing (SDB) terhadap tekanan dara pasien hipertensi.

Jenis jurnal : Jurn

wilayah keja puskesmas kabupate

Jenis intervensi :

erapi komplementer (progressive muscle relaxation dan SDBE)

Durasi:

progressive muscle relaxation dan slow deep breating dilakukan

Frekuensi:

berusia 18-60 tahun, Sistole 140 - 180

$\mathrm{mmHg}$, Telah terdiagnosis hipertensi

Jenis metodologi penelitian:

tanpa komplikasi, tidak mendapat ob

dengan baik dan bersedia menjadi

responden.
Kriteria ekslusi :

Pasien menderita patah tulang, strain

Instrument : Sphygmomanometer digital dan lembar observasi untuk

mencatat tekanan darah.

Peneliti datan ke puskesmas untuk mendapat data responden dan melakukan

pemilihan responden yang sesuai dengan kriteria inklusi, setealah itu

membuat kontrak waktu, penelti dibantu oleh asisten peneliti lalu

melakuakan pemeriksaan tekana darah jika tekanan darah masuk dalam

Analisa dat

Analisa data dalam penelitian ini menggunakan kruskal-wallis dilanjutkan dengan post-hoc post-hoc

\begin{tabular}{|c|c|}
\hline $\begin{array}{l}\text { Pada penelitian ini } \\
\text { dilakukan intervensi } \\
\text { pembanding yaitu } \\
\text { Terapi slow deep } \\
\text { breating untuk } \\
\text { menurunkan tekanan } \\
\text { darah. }\end{array}$ & $\begin{array}{l}\text { Hasil : Terdapat penurunan TD sistolik dan diastol } \\
\text { setelah dilakuakn intervensi pada semua kelomok } \\
\text { tidak terdpat terbedaan efektifitas yang signifikan } \\
\text { antara ketiga kelompok setelah diberikan intervens } \\
\text { waktu optmal penurunan TD sistolik pada kelompo } \\
\text { PMR dan SDBE pada hari ke 3. Jika dilihat dari ha } \\
\text { mean }\end{array}$ \\
\hline
\end{tabular}

Literat

ure

Review

Terapi

Nonfar

makolo

gi Pada

Pasien

ESRD 


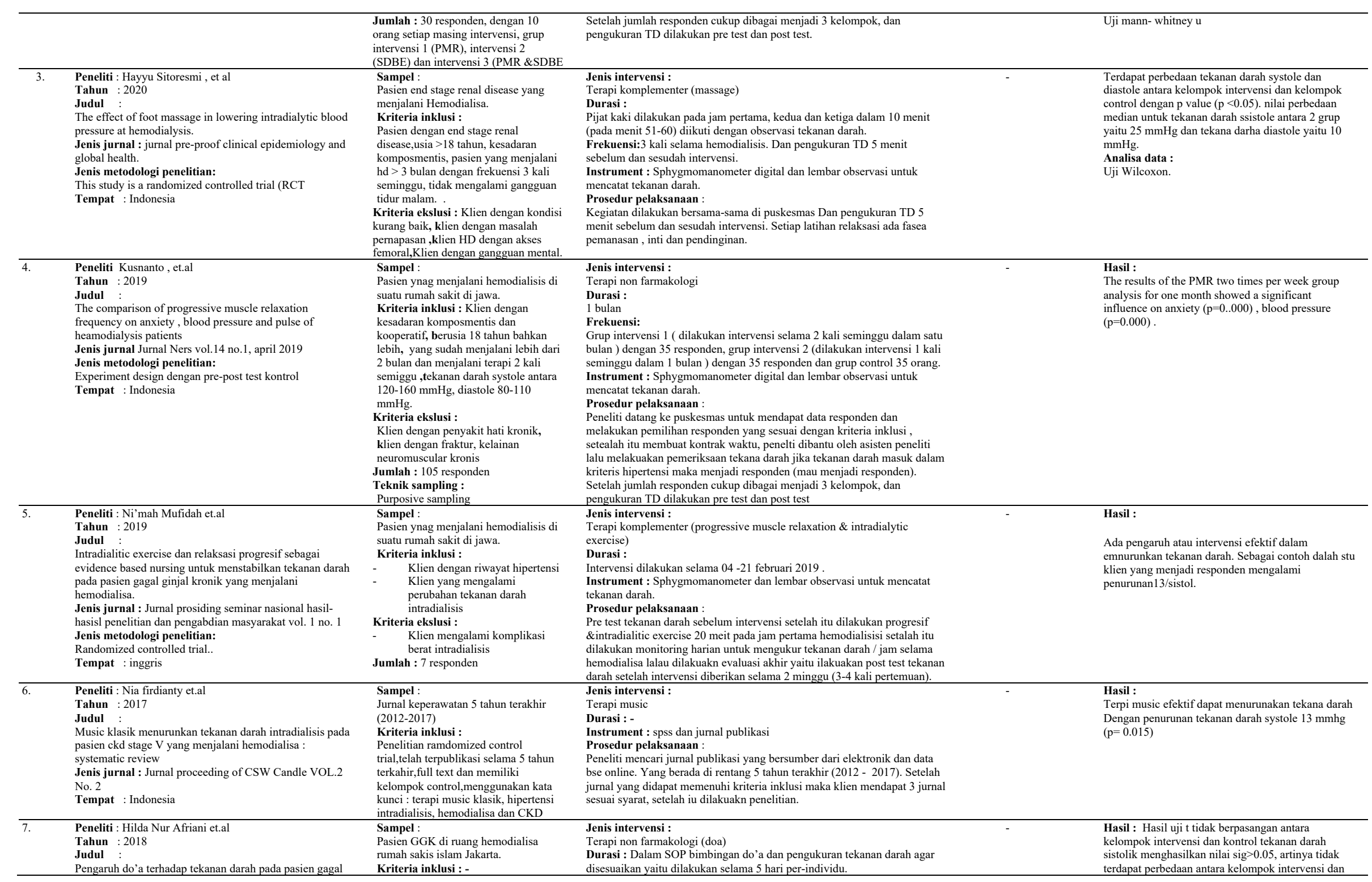


Jurnal Keperawatan Wiyata

Volume 1, Nomor 1, Tahun 2020

ISSN 2774-4558 (Cetak)

ISSN 2774-9789 (Online)

\begin{tabular}{|c|c|c|c|c|}
\hline & $\begin{array}{l}\text { ginjal kronis (GGK) Pre- Hemodialisis } \\
\text { Jenis jurnal : Jurnal keperawatan Sialmpari vol } 2 \text { no.1 } \\
\text { Jenis metodologi penelitian: } \\
\text { Quasi Experiment } \\
\text { Tempat : Indonesia }\end{array}$ & $\begin{array}{l}\text { Kriteria ekslusi : - } \\
\text { Jumlah : } 32 \text { responden (16 kelompok } \\
\text { intervensi dan } 16 \text { kelompok control }) \\
\text { Teknik sampling: } \\
\text { Purposive samplng }\end{array}$ & 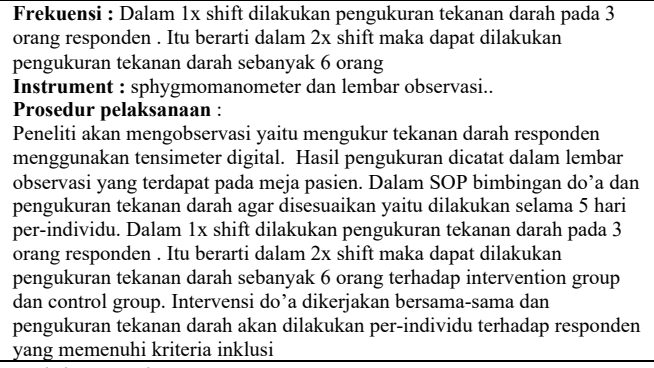 & $\begin{array}{l}\text { kontrol sedangkan tekanan darah diastolik } \\
\text { menghasilkan nilai sig<0.05, artinya terdapat } \\
\text { perbedaan antara kelompok intervensi dan kontrol. } \\
\text { Simpulan, pemberian intervensi do'a pada } \\
\text { prehemodialysis terbukti dapat menurunkan tekanan } \\
\text { darah } \\
\text { Analisa data : } \\
\text { Hasil uji T berpasangan. }\end{array}$ \\
\hline 8. & $\begin{array}{l}\text { Peneliti : Matthew J. Clarkson et.al } \\
\text { Tahun : } 2017 \\
\text { Judul } \\
\text { Efficacy of blood flow restriction exercise during dialysis } \\
\text { for end stage eranl disease patients : protocol of } \\
\text { randomized controlled trial } \\
\text { Jenis surnal I Jurnal BMC Nephrology (2017) } 18: 294 \\
\text { Jenis metodologi penelitian: } \\
\text { randomised controlled trial design }\end{array}$ & 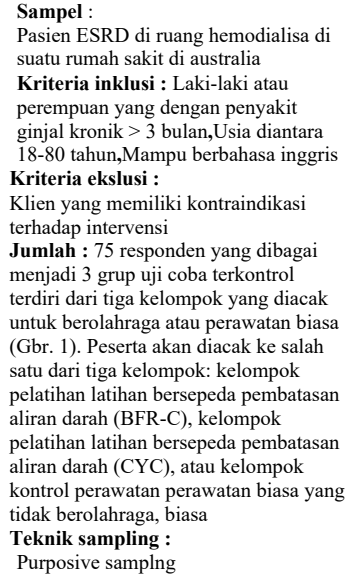 & $\begin{array}{l}\text { Jenis intervensi : } \\
\text { Terapi non farmakologi exercise } \\
\text { Durasi : } 3 \text { bulan } \\
\text { Frekuensi : } 3 \text { kali semingggu } \\
\text { Instrument : sphygmomanometer dan lembar observasi, sepeda. } \\
\text { Prosedur pelaksanaan : } \\
\text { Peserta akan dialokasikan untuk kelompok bersepeda pembatasan aliran } \\
\text { darah, kelompok bersepeda tradisional atau kelompok kontrol perawatan } \\
\text { biasa. Kedua kelompok yang berolahraga akan menyelesaikan } 3 \text { bulan } \\
\text { latihan bersepeda, dilakukan secara intradialititi, tiga kali seminggue. } \\
\text { Kelompok bersepeda pembatasan aliran darah akan menyelesaikan dua } \\
\text { pertandingan bersepeda } 10 \text { menit yang dipisahkan oleh istirahat } 20 \text { menit } \\
\text { dengan upaya subyektif } 15 \text { menit pada skala peringkat } 6 \text { hingga } 20\end{array}$ & $\begin{array}{l}\text { Hasil : } \\
\text { : Penelitian ini akan menentukan kemanjuran latihan } \\
\text { pembatasan aliran darah di antara pasien dialisis } \\
\text { untuk meningkatkan hasil fisiologis utama yang } \\
\text { memengaruhi independensi dan kualitas hidup, } \\
\text { dengan pengurangan beban pada pasien. Ini mungkin } \\
\text { memiliki implikasi yang lebih luas untuk populasi } \\
\text { klinis lain dengan penurunan kesehatan otot dan } \\
\text { fungsi fisik yang sama, dan mereka } \\
\text { dikontraindikasikan untuk intensitas latihan yang } \\
\text { lebih tinggi. }\end{array}$ \\
\hline 9. & $\begin{array}{l}\text { Peneliti : Catur sayekti . et.al } \\
\text { Tahun : } 2015 \\
\text { Judul }: \\
\text { Pengaruh Terapi Music Terhadap Penurunan Tekanan } \\
\text { Darah Pada Pasien Post Hemodialisa Di RSUD Prof Dr. } \\
\text { Margono Soekarjo Purwokerto } \\
\text { Jenis surnal I Jurnal Viva Medika vol. } 8 \text { no. } 15 \\
\text { Jenis metodologi penelitian: } \\
\text { Quasi Experiment Design, pendekatan penelitian yang } \\
\text { digunakan yaitu non equivalent control group. Tempat : } \\
\text { Indonesia }\end{array}$ & $\begin{array}{l}\text { Sampel : } \\
\text { Pasien post hemodialisa RSUD Prof. } \\
\text { Dr. Margono Sockarjo Purwokerto } \\
\text { Kriteria inklusi :- } \\
\text { Kriteria ekslusi :- } \\
\text { Jumlah Sampel pada penelitian ini } \\
\text { sebanyak } 2 \text { responden yang terbagi } \\
\text { menjadi } 2 \text { kelonpok yaktu } 10 \text { kelompok } \\
\text { perlakuan dan } 10 \text { kelompok kontrol } \\
\text { Teknik sampling: } \\
\text { Purposive samplng }\end{array}$ & $\begin{array}{l}\text { Jenis intervensi : } \\
\text { Terapi Musik } \\
\text { Durasis : - } \\
\text { Frekuensi : pre dan post intervensi } \\
\text { Instrument : spygmomanometer clock merk range dan stetoskop merk } \\
\text { riester dengan hasil kalibrasi } \pm 1,2 \mathrm{mmHg} \\
\text { Prosedur pelaksanaan : } \\
\text { Teknik pengumpulan data dalam penelitian ini adalah dengan pengukuran } \\
\text { tekanan darah sebelum dan sesudah mendapatkan terapi musik, kemudian } \\
\text { dipindahkan dalam master tabel. Analisis yang digunakan dalam penelitian }\end{array}$ & $\begin{array}{l}\text { Hasil : } \\
\text { Analisis yang digunakan adalah uji beda dan regresi } \\
\text { logistik. Hasil penelitian menunjukkan bahwa ada } \\
\text { perbedaan sistolik tekanan darah pada kelompok } \\
\text { eksperimen dan tidak ada perbedaan pada kelompok } \\
\text { kontrol }((p=0,001<0,05),(p=0,180>0,05))\end{array}$ \\
\hline
\end{tabular}


Jurnal Keperawatan Wiyata

Volume 1, Nomor 1, Tahun 2020

ISSN 2774-4558 (Cetak)

ISSN 2774-9789 (Online)

\begin{tabular}{|c|c|c|c|c|c|}
\hline 10. & $\begin{array}{l}\text { Peneliti : Francesco Burrain . et.al } \\
\text { Tahun : } 2018 \\
\text { Judul : } \\
\text { Effects of listening to live singing in patients undergoing } \\
\text { hemodialysis : A Randomized Controlled Crossover Study } \\
\text { Jenis jurnal: Biological Research for Nursing 1-9 } \\
\text { Jenis metodologi penelitian: } \\
\text { Randomized Controlled Crossover Study } \\
\text { Tempat : Italy }\end{array}$ & $\begin{array}{l}\text { Sampel : } \\
\text { Pasien dari the Dialysis and Renal } \\
\text { Transplant Unit of the St. Orsolal } \\
\text { Universitit Hospital in Bologna, Italy } \\
\text { Kriteria inklusi : } \\
\quad \text { Pasien dengan diagnoasa ESRD } \\
\quad \text { on hd } \\
-\quad \text { Usia }>18 \text { tahun } \\
\quad \text { Klien yang sudah menyetujui } \\
\quad \text { informed consent } \\
\text { Kriteria ersslusi : } \\
\quad \quad \text { Pasien yang mangalami } \\
\quad \text { gangguan pendengaran. } \\
\text { Jumlah Sampel pada penelitian ini } \\
\text { sebanyak } 24 \text { responden }\end{array}$ & 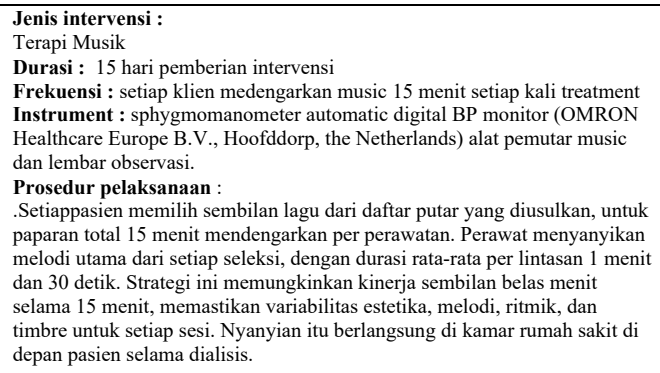 & $\begin{array}{l}\text { Terapi yang diberikan } \\
\text { rumah sakit pada saat } \\
\text { menjalani hemodialisa. }\end{array}$ & $\begin{array}{l}\text { Hasil : } \\
\text { Mendengarkan music secara langsung dapat } \\
\text { mempenagruhi tekanan darah baik sisitole walaupun } \\
\text { diastole }(\mathrm{p}<0,05)\end{array}$ \\
\hline 11. & $\begin{array}{l}\text { Penelitit : Stephanie T. et.al } \\
\text { Tahun : : 2019 } \\
\text { Judul : } \\
\text { The effect of exercise on blood pressure in chronic kidney } \\
\text { disease : A systematic review and meta - analysis of } \\
\text { randomized controlled trials } \\
\text { Jenis jurnal : Journal.pone. } 0211032 \\
\text { Jenis metodologi penelitian: } \\
\text { Systematic review and meta- analysis of RCT } \\
\text { Tempat : Italy }\end{array}$ & $\begin{array}{l}\text { Sampel : } \\
12 \text { jurnal dengan } 505 \text { partisipan } \\
\text { Kriteria inklusi : } \\
\text { Jurnal yang membahas tentang exercise } \\
\text { yang effektif untuk menurunkan } \\
\text { tekanan darah pada pasien ckd,jurnal } \\
\text { dengan metode RCT,exercise untuk } \\
\text { menurunkinkan tekanan darah pada pasien } \\
\text { Non CKD }\end{array}$ & $\begin{array}{l}\text { Jenis intervensi : Exercise } \\
\text { Waktu : penelitian November } 62017 \text { - agustus } 2018 \text {. } \\
\text { Prosedur pelaksanaan: Pencarian komprehensif yang dirancang oleh } \\
\text { pustakawan terlathih MLIS dilakukan untuk mengidentifikasi semua uui coba } \\
\text { terkontrol secara acak pada orang dewasa dengan CKD non-dialisis yang } \\
\text { membandingan intervensi latihan dengan tidak ada intervensi olahraga atau } \\
\text { dengan bentuk latihan lain }\end{array}$ & & $\begin{array}{l}\text { Hasil: } \\
\text { Masih terbatas dari penelitian jangka pendek } \\
\text { menunjukkan bahwa olahraga merupakan strategi } \\
\text { potensial untuk menurunkan tekanan darah pada } \\
\text { PGK. Namun, untuk merekomendasikan olahraga } \\
\text { untuk mengontrol tekananan darah pada populasi ini, } \\
\text { diperlukan studi jangka panjang berkualitas tinggi } \\
\text { yang dirancang khusus untuk mengevaluasi } \\
\text { hipertensi. }\end{array}$ \\
\hline 12. & $\begin{array}{l}\text { Peneliti : Jiang Pu. et.al } \\
\text { Tahun : } 2017 \\
\text { Judul }: \\
\text { Efficacy and safety of intradialytic exercise in } \\
\text { haemodialysis patients : a systematic review and meta- } \\
\text { analysis } \\
\text { Jenis jurnal }: \text { Journal.bmjopen.2017-020633 } \\
\text { Jenis metodologi penelitian: } \\
\text { Systematic review and meta- analysis } \\
\text { Tempat : China }\end{array}$ & $\begin{array}{l}\text { Sampel: } \\
27 \text { jurnal dengan } 1215 \text { partisipan } \\
\text { Kriteria inklusi : } \\
\text { Uji coba terkontrol secara acak (RCT) } \\
\text { bertujuan untuk membandingkan } \\
\text { kemanjuran dan keamanan latihan } \\
\text { intradialitik versus tidak ada olahraga } \\
\text { pada apsien dewasa yang menjalani } \\
\text { hemodialisis selama minimal } 3 \text { bulan. } \\
\text { Jangka waktu program latihan minimal } \\
8 \text { minggu. } \\
\text { Jumlah Sampel pada penelitian ini } \\
\text { sebanyak } 27 \text { jurnal }\end{array}$ & $\begin{array}{l}\text { Jenis intervensi : } \\
\text { Intradialyytic Exercise } \\
\text { Waktu : penelitian maret } 2017 \\
\text { Prosedur pelaksanaan : } \\
\text { Data yang diambil dari studi yang disertakan adalah sebagai berikut: } \\
\text { (1) Waktu publikasi, penulis pertama dan negara; } \\
\text { (2) Karakteristik subjek (ukuran sampel, usia rata-rata dan jenis kelamin, } \\
\text { dll) } \\
\text { (3) Informasi rinci tentang latihan intradialitik (mode, intensitas, waktu dan } \\
\text { frekuensi, dll); } \\
\text { (4) Durasi tindak lanjut dan } \\
\text { (5) Hasil. Setiap ketidaksepakatan antara penulis review diselesaikan } \\
\text { dengan dukungan penulis review ketiga (SO). } \\
\text { Jika jurnal sudah masuk kriteria maka jurnal dapat diambil }\end{array}$ & & $\begin{array}{l}\text { Hasil : } \\
\text { Pencaian awal kami menghasilkan total } 1389 \\
\text { catatan, di antaranya, } 27 \text { melibatkan } 1.215 \text { pasien } \\
\text { yang gelevan dengan tinijaun sistematis kami.. Dari } \\
27 \text { studi ini, tiga tiga belajar lengan dengan } \\
\text { perbandingan tidak ada latihan, latihan ketahanan dan } \\
\text { latihan aerobik }\end{array}$ \\
\hline
\end{tabular}




\section{PEMBAHASAN}

End stage renal disease dengan hipertensi memiliki keterkaitan yang dimana penyebab tersering terjadinya end stage renal disease adalah tekanan darah tinggi, yaitu sekitar dua pertiga dari seluruh kasus (National Kidney Foundation, 2015). Hipertensi merupakan penyebab dominan pada klien end stage renal disease yang dijelaskan di dalam penelitian Saniya Ilma et.al (2017) dengan judul factor yang berhubungan dengan kejadian penyakit ginjal kronik pada penderita hipertensi di Indonesia yang dimana di dalam penelitiannya didapatkan hasil, bahwa prevalensi klien dengan penyakit ginjal kronis pada penderita hipertensi di Indonesia sekitar 0,5 \% (63 sampel ) dari 11.405 sampel.

Pada saat klien mengalami atau memiliki penyakit hipertensi (tekanan darah tinggi) yang tidak terkontrol dalam waktu lama atau klien tidak menjaga pola hidup(diet), atau patuh dalam minum obat yang lambat laut akan mempengaruhi system di dalam tubuh khususnya pada system perkemihan (ginjal ). Tekanan darah tinggi yang tidak terkontrol akan memberi efek yang buruk terhadap ginjal, yaitu hilangnya sejumlah besar nefron fungsional yang progresif dan irreversible. Peningkatan tekanan dan regangan yang kronik pada arteriol dan glomeruli diyakini dapat menyebabkan sklerosis pada pembuluh darah glomeruli atau yang sering disebut degan glomerulosklerosis. Penurunan jumlah nefron akan menyebabkan proses adaptif, yaitu meningkatnya aliran darah, peningkatan LFG (Laju Filtrasi Glomerulus) dan peningkatan keluaran urin di dalam nefron yang masih bertahan. Proses ini melibatkan hipertrofi dan vasodilatasi nefron serta perubahan fungsional yang menurunkan tahanan vaskular dan reabsorbsi tubulus di dalam nefron yang masih bertahan. Perubahan fungsi ginjal dalam waktu yang lama dapat mengakibatkan kerusakan lebih lanjut pada nefron yang ada. Lesi-lesi sklerotik yang terbentuk semakin banyak sehingga dapat menimbulkan obliterasi glomerulus, yang mengakibatkan penurunan fungsi ginjal lebih lanjut, dan menimbulkan lingkaran setan yang berkembang secara lambat yang berakhir sebagai penyakit end stage renal disease (Guyton and Hall, 2007).

Klien End stage renal disease juga bisa menderita hipertensi. Pada klien end stage renal disease klien mengalami kerusakan pada ginjal atau pembuluh arteri pada ginjal yang menyempit dapat membatasi aliran darah ke ginjal. Kondisi ini memicu tubuh untuk meningkatkan produksi hormone yang disebut renin atau teraktivasinya system RAA (Renin-Angiotensin-Aldosteron).

Komplikasi yang terjadi pada saat Hemodialisis yaitu hipertensi sangat berbahaya dan perlu diantisipasi karena bisa menimbulkan dilatasi jantung, stroke, gagal 
jantung dan kematian.untuk mengantisipasi diperlukan sebuah terapi baik secara farmakologi (medis) maupun nonfarmakologi (keperawatan). Hasil penelitian Terapi nonfarmakologi dapat dilakukan untuk membantu klien mengatasi peningkatan tekanan darah pasien dengan end stage renal disease dengan efek samping yang minimal. Terapi yang bisa digunakan seperti progresif muscle relaxation, terapi massase kaki, terapi music dan intradialitic exercise dengan hasil akhir yang diharapkan adalah penurunan tekanan darah pada pasien yang nantinya akan mencegah terjadi komplikasi lebih lanjut dan menyebabkan peningkatan morbiditas dan mortalitas pada pasien end stage renal disease.

\section{REFERENSI}

Afriani, Hilda Nur ., et.al (2018). Pengaruh Do'a Terhadap Tekanan Darah Pada Pasien Gagal Ginjal Kronis (Ggk) Pre-Hemodialysis. urnal Keperawatan Silampari Volume 2, Nomor 1, Desember 2018. DOI:

https://doi.org/10.31539/jks.v2i1.379

Agustina, E., Erman, E., \& Purnomo, A. R. (2019). Keterlaksaan pembelajaran saintifik berbasis kontekstual pada materi zat adiktif. e-Journal Pensa, 7(2), 86-93

Ariva,S I., et.al (2017). Faktor Yang Berhubungan Dengan Kejadian Penyakit Ginjal Kronik Pada Penderita Hipertensi Di Indonesia . Jurnal MKMI Vol.13 No:4

Armiyati, Y. (2009). Komplikasi intradialisis yang dialami klien CKD saat menjalani Hemodialisa di RS
PKU Muhammadiyah Yogyakarta. Depok Indonesia: Universitas Indonesia

Astuti,Nur Muji., et.al (2017). Efektifitasstretching Exercise Dan Pernafasan Yoga Terhadap Regulasi Tekanan Darah Dan Kualitas Hidup Klien Esrd Yang Menjalani Hemodialisis Di Rumkital Dr. Ramelan Surabaya. Jurnal Ilmiah Kesehatan, Vol. 10, No. 2, Agustus 2017, Hal 226-233

Burrain, Francesco . ,et.al (2018). Effects of listening to live singing in patients undergoing hemodialysis : A Randomized Controlled Crossover Study. Biological Research for Nursing 1-9

Chazot and jean (2010), edisi 2 keperawatan kardiovaskuler, Jakarta :EGC

Daugirdas, J.T., Blake, P.B., \& Ing, T.S. (2007). Handbook of dyalisis. $4^{\text {th }}$ edition.Philadelphia: Lipincot William \& Wilkins.

Firdianty, Nia., et.al. (2017). Music klasik menurunkan tekanan darah intradialisis pada pasien ckd stage $\mathrm{V}$ yang menjalani hemodialisa. : Jurnal proceeding of CSW Candle VOL.2 No. 2

Fuatmi,Asti et.al (2017). "Faktor-Faktor Yang Mempengaruhi Kejadian Hipertensi Intradialitik Pada Pasien Gagal Ginjal Kronik (Ggk) Di Instalasi Hemodialisa Rumah Sakit Dr. Soedirman Kebumen".Jurnal Keperawatan.

Inrig, J.K., Oddone, E.Z., Hasselblad, V., Gillespie, B., Patel, U.D., Reddan, Toto, R., Himmelfarb, J., Winchester, J.F., Stivelman, J., Lindsay, R.M., \& Szczech, L.A., (2007). Association of intradialytic blood pressure changes with hospitalization and mortality rates in prevalent ESRD patients. Kidney International. 71.454-461. 
Kusnanto, et.al (2019). The comparison of progressive muscle relaxation frequency on anxiety, blood pressure and pulse of heamodialysis patients . Jurnal Ners vol.14 no.1, april 2019

Mufidah, Ni'mah., et.al. (2019). Intradialitic exercise dan relaksasi progresif sebagai evidence based nursing untuk menstabilkan tekanan darah pada pasien gagal ginjal kronik yang menjalani hemodialisa. Jurnal prosiding seminar nasional hasil-hasisl penelitian dan pengabdian masyarakat vol. 1 no. 1

National Kidney Foundation. (2015). Clinical practice guidelines clinical K/DOQI practice guidelines for Chronic Kidney Disease: evaluation, classification and stratification. New York: NKF

PENEFRI. 7th Report Of Indonesian Renal Registry. 2014.Available from: URL: http:// www.indonesianrenalregistry.org. Accessed Juni 19, 2020.

Riset Kesehatan Dasar (2013). Badan Penelitian dan Pengembangan Kesehatan Kementerian RI tahun 2013. Diakses tanggal 16 JUNI 2020 darihttp://www.depkes.go.id/resourc es/download/general/Hasil\%20Riske sdas \%202013.pdf

Sartika , Andry (2018). progressive muscle relaxation (PMR) dengan slow deep breathing (SDB) terhadap tekanan darah pasien hipertensi. Jurnal keperawatan Silampari, voleme 2, no.1, desember 2018

Sayekti, Catur., et.al (2015). Pengaruh Terapi Music Terhadap Penurunan Tekanan Darah Pada Pasien Post Hemodialisa Di RSUD Prof Dr. Margono Soekarjo Purwokerto. Jurnal Viva Medika vol. 8 no. 15

Sitoresmi H, Masyitha Irwan A, Sjattar EL, Usman S, The effect of foot massage in lowering intradialytic blood pressure at Hemodialysis Unit in Indonesian Hospital, Clinical Epidemiology and Global Health (2020), doi:

https://doi.org/10.1016/j.cegh.2020.0 4.026 .

Thomas, N. (2003). Renal nursing. $2^{\text {nd }}$ edition. Philadelphia: Elsevier Science.

Tomson, C.R.V., (2009). Blood pressure and outcome in patients on dialysis. The Lancet. 373 (9668).981-9 
Jurnal Keperawatan Wiyata

Volume 1, Nomor 1, Tahun 2020

ISSN 2774-4558 (Cetak)

ISSN 2774-9789 (Online) 